\title{
DNA-Binding Protein Inhibitor ID-1
}

National Cancer Institute

\section{Source}

National Cancer Institute. DNA-Binding Protein Inhibitor ID-1. NCI Thesaurus. Code C99650.

DNA-binding protein inhibitor ID-1 (155 aa, 16 kDa) is encoded by the human ID1 gene. This protein plays a role in the modulation of gene transcription. 